\title{
The Effect of Shape and Arrangement of End Sill Stepped Cascade Weirs on Water Quality
}

\author{
Karim Rashid Gubashi \\ Batool Ali Hussain \\ Environmental Eng. Dep., Al-Mustansiriyah Uni., Baghdad, IRAQ \\ karimgubashi@yahoo.com \\ batoolali53@yahoo.com \\ Received: 14-08-2017 Revised: 27-11-2017 Accepted: 04-Jan.-2018 \\ http://doi.org/10.29194/NJES21020199
}

\begin{abstract}
Hydraulic structures can be accepted as the key components in improving aeration efficiency because of the strong turbulent mixing associated with substantial air bubble entrainment at these structures. Different hydraulic structures have been designed to enhance aeration such as stepped cascades. A laboratory model of stepped cascade weir with five different shapes of end sill (normal, triangle, rectangle1, rectangle2 and rectangle3) have been installed at $\mathrm{Al}$ Mustansiriya University, College of Engineering to evaluate treatment system and reduced pollutants in marginal water for different flow rates $(35,60$ and $80 \mathrm{~L} / \mathrm{min})$. Results indicate that high removal efficiency of all pollutants parameter $\left(\mathrm{Cu}, \mathrm{Cr}, \mathrm{Mo}, \mathrm{Br}, \mathrm{Fe}, \mathrm{Mn}, \mathrm{Zn}, \mathrm{PO} 4, \mathrm{Cl}^{-}\right.$, $\mathrm{ClO} 2$, Hardness as $\mathrm{CaCO}_{3}, \mathrm{NH}_{3}, \mathrm{NO}_{2}$, Toxic matter) is for rectangle 1 shape at $\mathrm{Q}=60 \mathrm{~L} / \mathrm{min}$. High aeration efficiency is $45.7 \%$ for rectangle 1 shape at $\mathrm{Q}=80 \mathrm{~L} / \mathrm{min}$. High removal efficiency for $\mathrm{BOD}_{5}$ and COD are $48 \%$ and $47 \%$ respectively for rectangle 1 at $\mathrm{Q}=80 \mathrm{~L} / \mathrm{min}$.
\end{abstract}

Keywords: Stepped cascade, marginal water, hydraulic structures.

\section{1- Introduction}

Many different types of wastewater are produced by domestic and industrial sources [1]. Marginal quality water is defined as that which poses a threat to sustainable agriculture and/or human health by virtue of its quality, but which can be used safely for irrigation provided certain precautions are taken [2]. Hydraulic structures such as stepped cascades increase the amount of dissolved oxygen in a river system, even though the water is in contact with the structure for only a short time [3]. Stepped chutes cause vigorous turbulence of the water as it flows over it through a significant residence time .This shall enhance the air-water mass transfer of chemicals as the amount of air bubbles increase the surface area and consequently raise the concentration of dissolved oxygen. Thus stepped chutes are used also for in- stream re-aeration and in water treatment plants to enhance the air- water transfer of atmospheric gases (e.g. oxygen ) and of volatile organic components [4] . Cascade has been utilized as a hydraulic structure for years. It has proved to be the least costly aeration system in replenishing dissolved oxygen [5]. Dissolved oxygen (DO) is a major contributor to wastewater quality, where aerobic bacteria breathe oxygen to decompose the organic matters. According to adopted treatment processes, the proposed aeration system may differ from extensive use of mechanical systems for oxygen transfer to biological reactors in large wastewater treatment facilities, to simple use of cascades for increasing oxygen concentrations in wastewater where appropriate [6]. Aeration is one of the most elemental techniques frequently employed in the improvement of the physical and chemical characteristics of water. the processes by which the aeration accomplishes the desired results are:

- Scrubbing action or Sweeping caused by the turbulence of water and air mixing together.

- Oxidation of certain metals and gases. [7].

This study aims to evaluate aeration efficiency of stepped cascade weirs system and evaluate removal efficiency of pollutant parameters from marginal water for different flow rates.

\section{2-Experimental Arrangement and Experiments}

Marginal water has been prepared from domestic waste and leachate wastewater. The laboratory model consist of inlet tank, inlet pump, transparent methacrylate cascade structure, recycling tank, recycling pump and outlet tank connected to each other by pipes, fittings and flow meter. The schematic representation of lab- scale unit is shown in Fig.1.

The cascade structure was constructed from three parts. The first part is a settling transparent methacrylate tank of dimension $(0.8 * 0.6 * 1.25) \mathrm{m}$, the second part is transparent methacrylate cascade steps of dimension $(2.44 * 0.23 * 1.25) \mathrm{m}$, the third part is a recycling transparent methacrylate tank of dimension $(2.44 * 0.25$ *0.36)m as shown in plate (1). Each part was made from a frame of iron angle connected to each other by welding and transparent methacrylate. In the settling tank there is a weir of 0.3 meter length and 0.23 meter width which calibrated to calculate the discharge as shown in plate (2). 


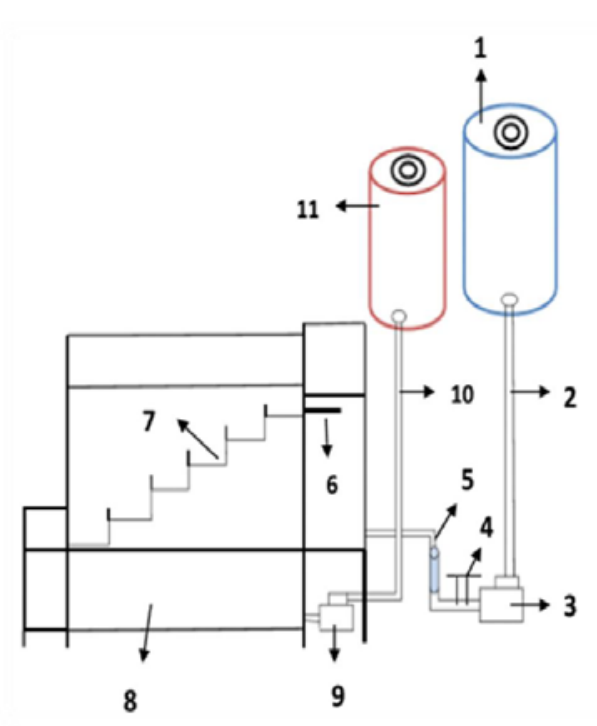

1- Inlet tank 5000 liters capacity

2- Pipe of diameter 2".

3-Electrical pump of $600 \mathrm{~L} / \mathrm{min}$.

4- Valve of diameter $2^{\prime \prime}$

5- Flow meter of $70 \mathrm{~L} / \mathrm{min}$ capacity

6- Weir of dimension $30^{*} 23 \mathrm{~cm}$

7- Cascade structure [ bay of dimension $40^{*} 23 \mathrm{~cm}$ and acrylic end sill of width $23 \mathrm{~cm}$ and height $14 \mathrm{~cm}$ ]

8- Recycling acrylic tank of dimension $244 * 25 * 36 \mathrm{~cm}$

9- Recycling electrical pump of $600 \mathrm{~L} \mathrm{~min}$

10- Recycling pipe of diameter $2 "$

11- Outlet tank 3000 liters capacity

Figure 1: schematic representation of lab- scale unit.

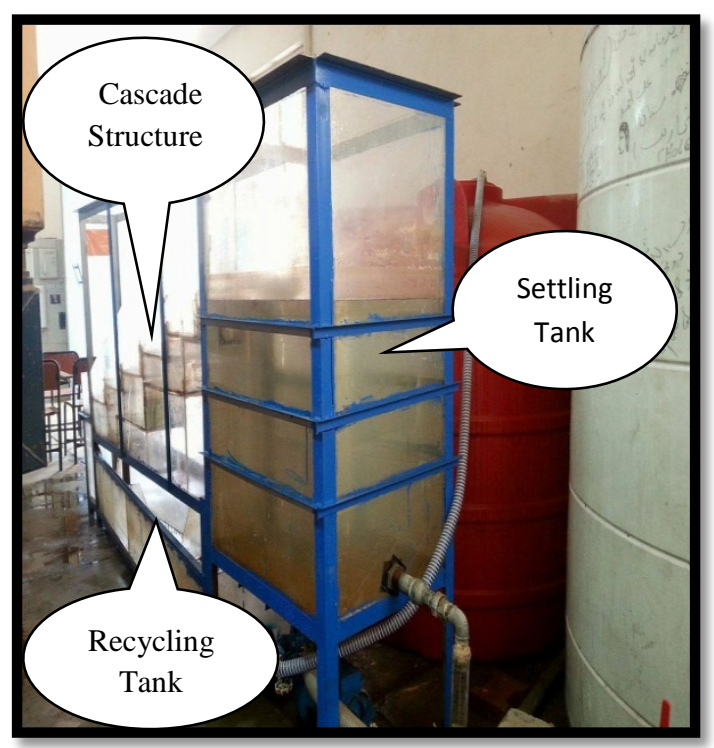

Plate 1: Arrangement of the cascade structure

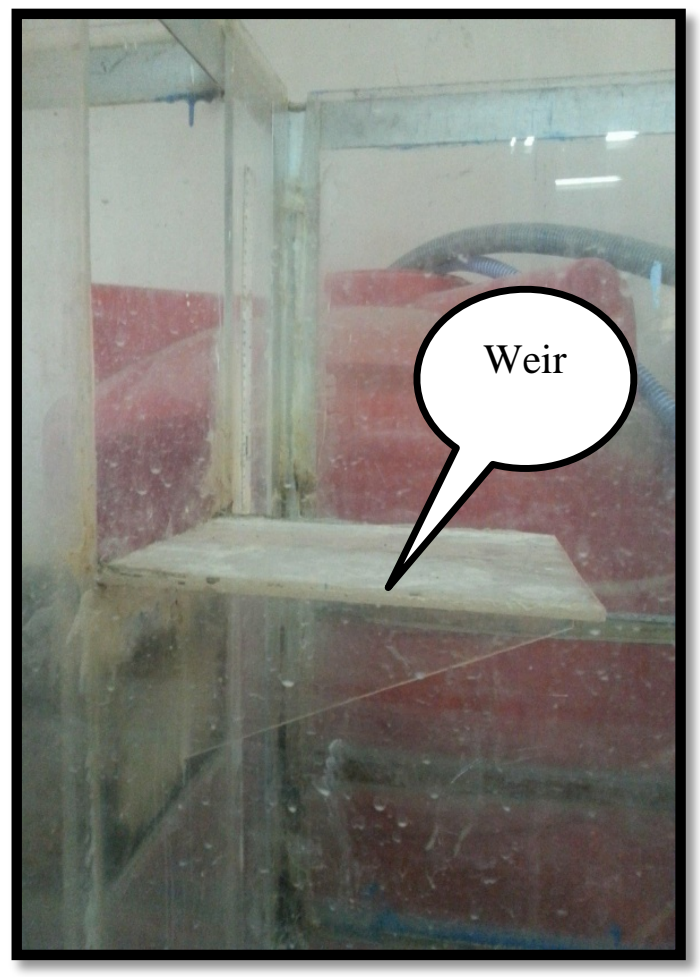

Plate 2: Weir

The inlet tank of 5000 liter volume connected to a pump of $600 \mathrm{~L} / \mathrm{min}$ which has been connected to flow meter by control valve for flow control. The recycling tank is connected to the outlet tank of 3000 liter volume by a recycling pump of discharge $600 \mathrm{~L} / \mathrm{min}$ as shown in plate(3) , plate(4), and plate(5).

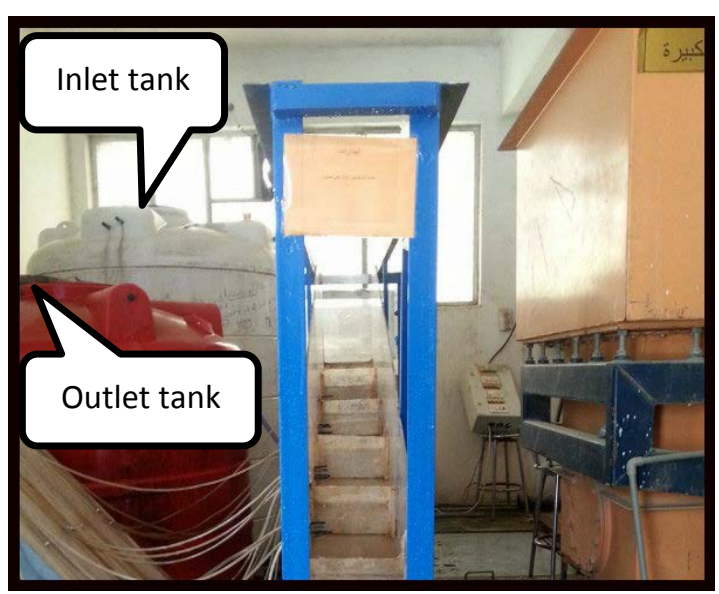

Plate 3: Inlet and outlet tank

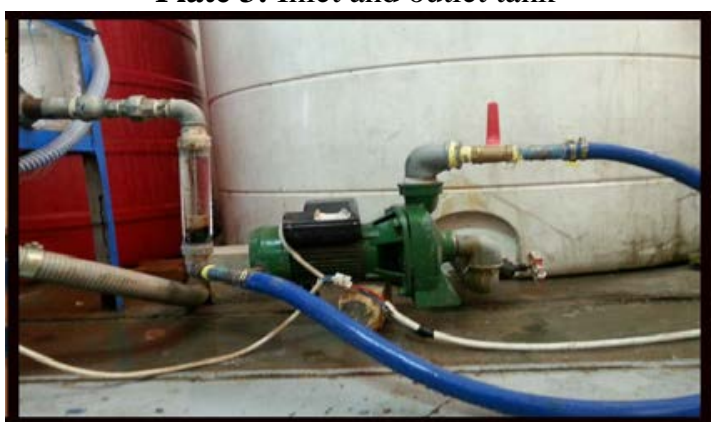

Plate 4: Inlet pump and flow meter 


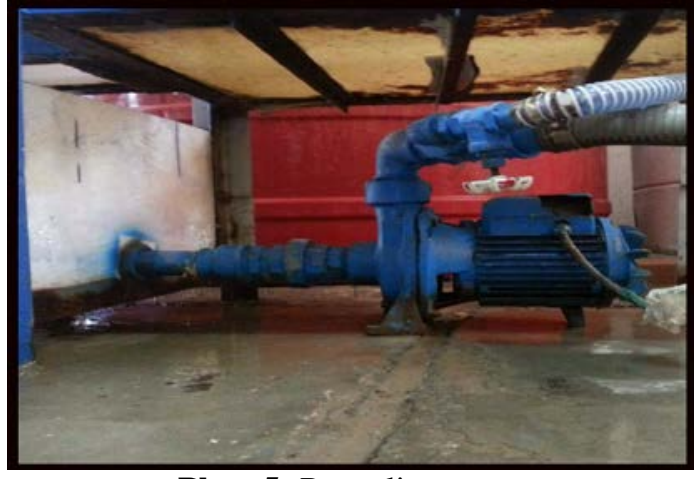

Plate 5: Recycling pump

Five different shapes of cascade weirs as shown in figure(2) is investigated and tested to increase dissolved oxygen in turbulent flow water .Three different values of flow rates (35, 60 and $80 \mathrm{~L} / \mathrm{min}$ ) are run in this study to evaluate removal efficiency of pollutant parameters from marginal water . properties of marginal water was measured before and after treatment in the(Ministry of Science and Technology Environment and Water Research and Technology Directorate - Water Research Center), ( University of Baghdad - College of Education for Pure Sciences Ibn Al-Haitham The central service Laboratory) and (AlMustansiriayah University - Environment Department - Water Laboratory).

These measured parameters are organic pollutants $\left(\mathrm{BOD}_{5}, \mathrm{COD}\right)$, inorganic pollutants (heavy metals (Copper(Cu),Chromium(Cr), Molybdenum (Mo), Bromine (Br), Iron(Fe), Manganese $(\mathrm{Mn})$, Zinc $(\mathrm{Zn}))$, phosphate $\left(\mathrm{PO}_{4}\right)$, Chlorine (Cl-), Chlorine Dioxide $\left(\mathrm{ClO}_{2}\right)$, Hardness as $\mathrm{CaCO}_{3}$, Ammonia $\left(\mathrm{NH}_{3}\right)$, Nitrite $\left(\mathrm{NO}_{2}\right)$, aeration efficiency and Toxic matter.
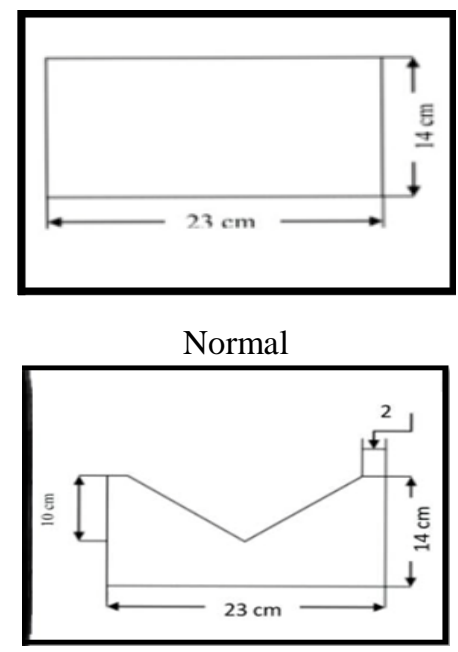

Triangle
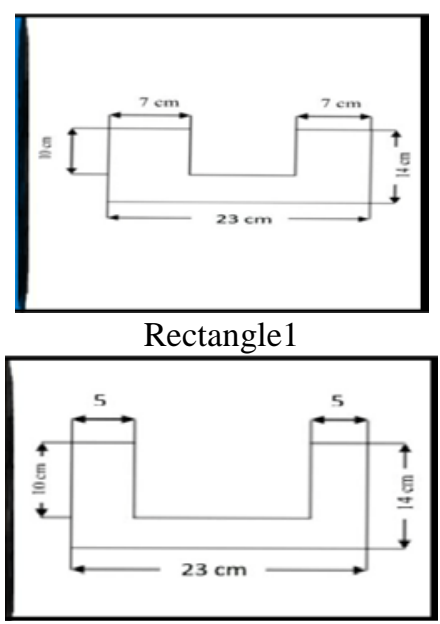

Rectangle2

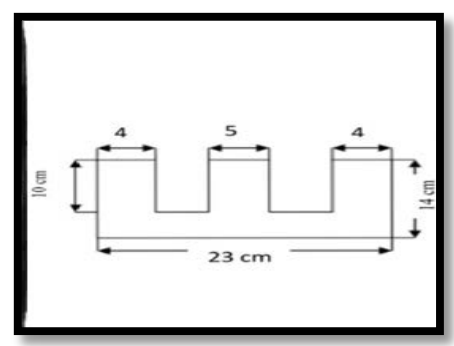

Rectangle3

Figure 2: Shapes of cascade weirs

Temperature correction factor is the one developed by (Gulliver et al, 1990).

$$
E_{20}=1-(1-E)^{1 / f}
$$

Where:

$\mathrm{E}$ : is the aeration efficiency at the water temperature of measurement $(\mathrm{T})$ in $^{\circ} \mathrm{C}$.

$\mathrm{E}_{20}$ : The aeration efficiency at temperature $20^{\circ} \mathrm{C}$. $\mathrm{f}$ : is described by :

$$
\mathrm{f}=1.0+0.021(\mathrm{~T}-20)+8.26 * 10^{-5}(\mathrm{~T}-20)^{2}
$$

\section{3- Oxygen Transfer Process:}

The rate of mass transfer, $d m / d t$ of oxygen from the atmosphere to the body of the turbulent liquid generally is proportional to the difference between the existing concentration $C$ and the equilibrium or saturation concentration $C s$ of oxygen in the liquid. It can be expressed as:

$$
\frac{d m}{d t}=\frac{d C}{d t}=\mathrm{KL} \frac{A}{V}(\mathrm{Cs}-\mathrm{C})
$$

Where $\mathrm{C}$ is $\mathrm{DO}$ concentration, $\mathrm{KL}$ is the coefficient of diffusion of oxygen in the liquid, A is surface area associated with the volume, $\mathrm{V}$, over which transfer occurs, $\mathrm{Cs}$ is saturation concentration, and $\mathrm{t}$ is time. The term $\mathrm{A} / \mathrm{V}$ is often called the specific surface area, a, or surface area per unit volume. 
For a hydraulic structure, the overall oxygen transfer may be measured by the deficit ratio $r$ defined as:

$$
\mathrm{r}=[(\mathrm{Cs}-\mathrm{Cu}) /(\mathrm{Cs}-\mathrm{Cd})]
$$

Where $\mathrm{C}_{\mathrm{u}}$ is the upstream dissolved oxygen concentration and $C_{d}$ is the dissolved oxygen concentration at the downstream end of the channel.

The oxygen transfer efficiency (aeration efficiency), E, may be defined as (Gulliver et al. 1990):

$$
\mathrm{E}=\frac{\mathrm{Cd}-\mathrm{Cu}}{\mathrm{Cs}-\mathrm{Cu}}=1-\frac{1}{r}
$$

$\mathbf{r}$ is the oxygen deficit ratio. The saturation concentrations Cs were determined by the chart of McGhee (1991).

According to Henry's Law, liquid temperature has a direct proportional effect on the solubility of gas in liquid, the most often used.

Collecting process of (DO) and $\left(\mathrm{BOD}_{5}\right)$ samples where in Winkler bottles $250 \mathrm{ml}$ (white bottle for $\mathrm{DO}$ and dark bottle for $\mathrm{BOD}_{5}$ ) as shown in plate (4).

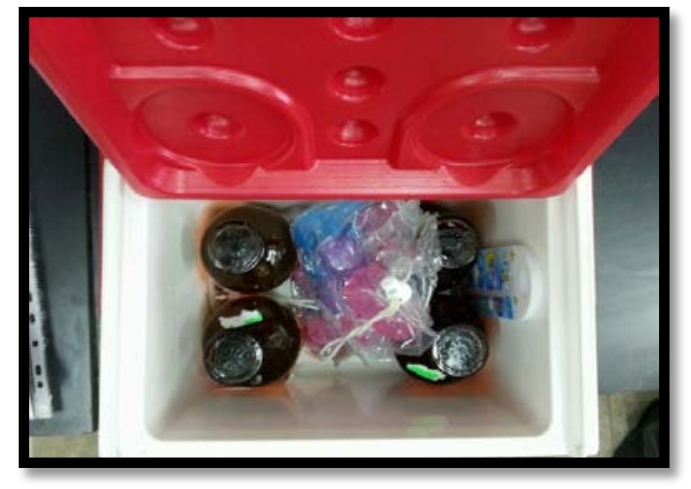

Plate 4: Winkler bottles in cooling portfolio

\section{4- Results and Discussion}

\section{4-1 Dissolved oxygen and aeration efficiency $\left(E_{20} \%\right)$}

The results illustrated that the level of DO has increased as the marginal water discharged over the stepped cascade. This could be attributed to the air bubbles entrained during the aeration process similar to the findings of [8]. The mechanism of aerating over weirs includes three steps. The first one includes minor aeration from water flowing over the weir directly to the jet. The second includes aeration on the surface of the pool from the jet depending on the intensity of surface agitation. The third and most contributing to the oxygenation process is the bubble aeration from air entrained in the jet and pool to which the jet is discharging [9].

The discharge of the marginal water over the steps has caused turbulence at the water surface which caused the appearance of the white foam at the surface as shown in plate (5).
However it is observed that the amount of white foam is increased as the discharge is increased.

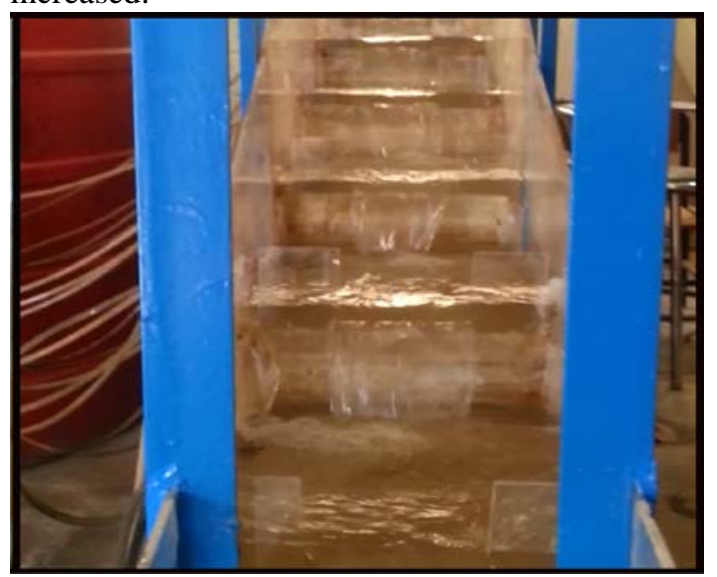

Plate 5: Appearance of air bubbles on the water surface due to aeration (Rectangle1)

Figure (3) represent the aeration efficiency for different flow rates, the figure shows that maximum aeration efficiency for the rectangle 1 shape at $\mathrm{Q}=80 \mathrm{~L} / \mathrm{min}$ is $45.7 \%$ and the minimum aeration efficiency for normal shape at $Q=35$ $\mathrm{L} / \mathrm{min}$ is $23 \%$.

The aeration efficiency for weirs varies with discharge. The aeration efficiency decreases with an increase in discharge. Novak (1973 and 1978) and Van der Kroon (1969 and 1969) reported a constant increase in the aeration efficiency with decreasing discharge. At low discharges, on the other hand, breakup of the jet is observed as drop height increases, this leads to reduced penetration and bubble contact time into the downstream water pool and so reduced aeration efficiency [10]. In this study the results show that aeration efficiency increased as flow rates increased, aeration efficiency was greatest with the rectangle 1 notch weir because increased discharge and small area result increased velocity of water and in turbulent mixing which will contribute to the oxygen transfer, and after effect high aeration. The weir geometry defines jet shapes that are unique to each weir, and the oxygen transfer seems to strongly depend on these jet shapes.

\section{4-2 Removal efficiency of pollutant \\ Parameters}

From the results high removal efficiency were for rectangle 1 shape at $Q=60 \mathrm{~L} / \mathrm{min}$ for all pollutant parameters.

From figure (4) to figure (17) observe that greater Removal efficiency $\mathrm{E} \%$ was for rectangle 1 at $\mathrm{Q}=60 \mathrm{~L} / \mathrm{min}$ for all polluted element. For rectangle 1 at $\mathrm{Q}=60 \mathrm{~L} / \mathrm{min}$, maximum removal efficiency was for $\mathrm{NO}_{2}$ is $50.9 \%$ and minimum removal efficiency was for $\mathrm{Mn}$ is $15.13 \%$. 


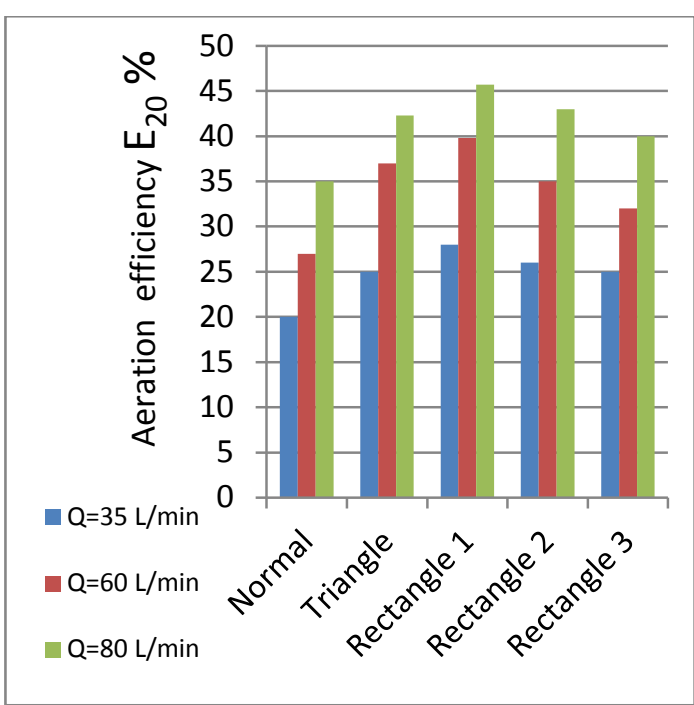

Figure 3: Relation between flow rates and aeration efficiency for all shapes

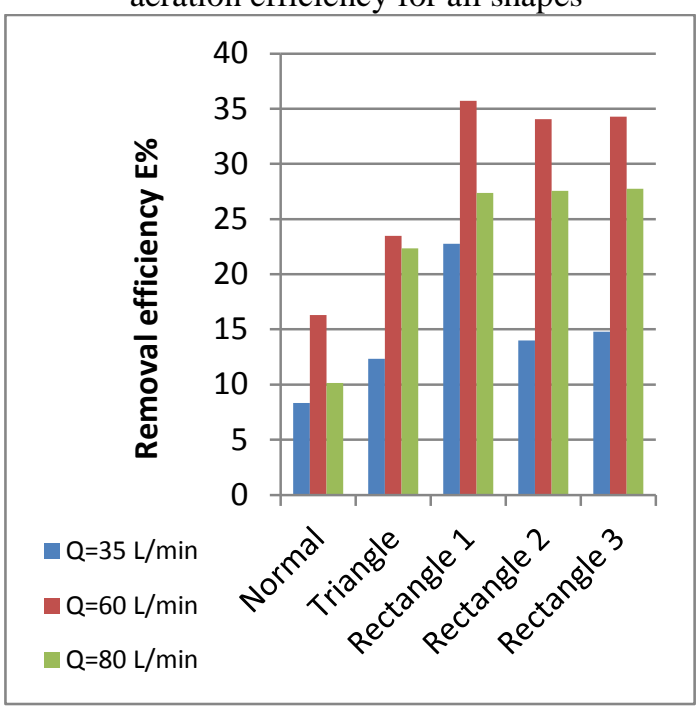

Figure 4: The relation between Removal efficiency $\mathrm{E} \%$ of $\mathrm{Cu}$ at different discharges for five shapes

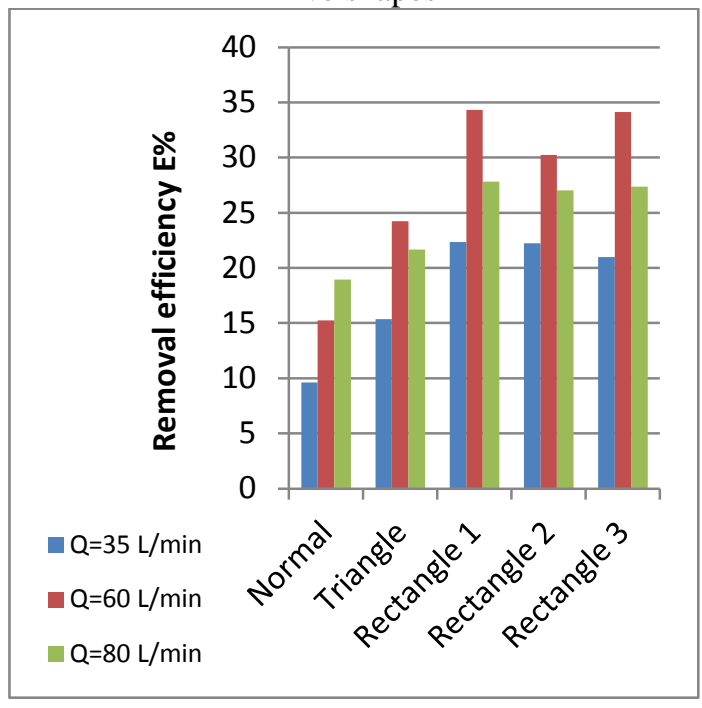

Figure 5: The relation between Removal efficiency $\mathrm{E} \%$ of $\mathrm{Cr}$ at different discharges for five shapes

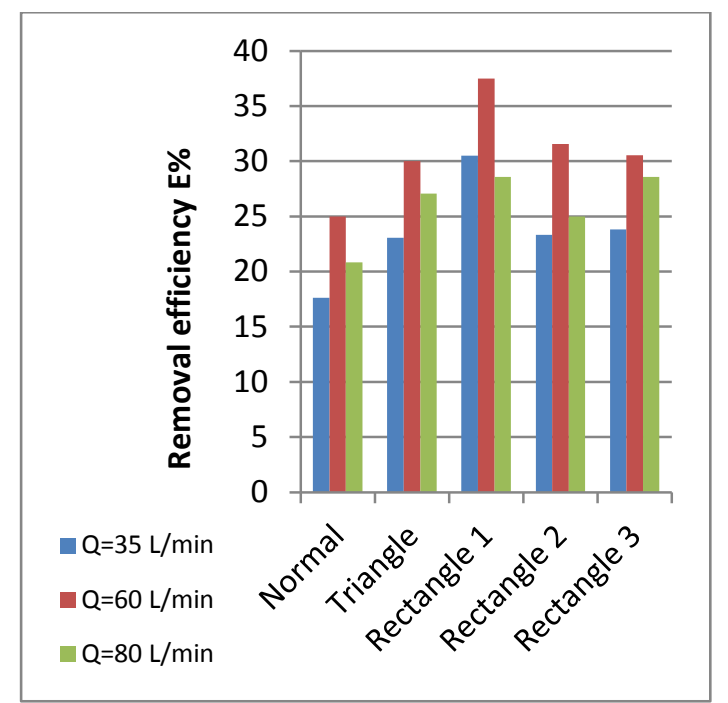

Figure 6: The relation between Removal efficiency $\mathrm{E} \%$ of Mo at different discharges for five shapes

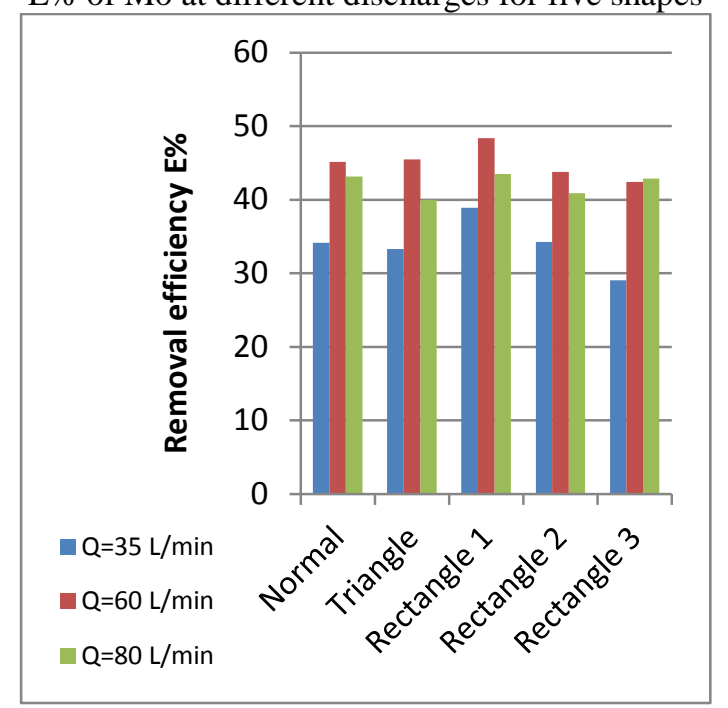

Figure 7: The relation between Removal efficiency $\mathrm{E} \%$ of $\mathrm{Br}$ at different discharges for five shapes

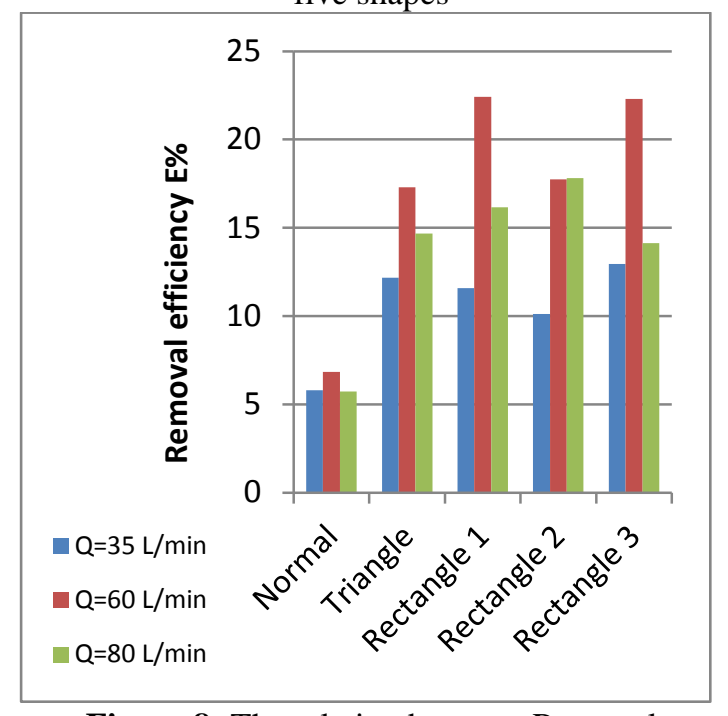

Figure 8: The relation between Removal efficiency $\mathrm{E} \%$ of $\mathrm{Fe}$ at different discharges for five shapes 


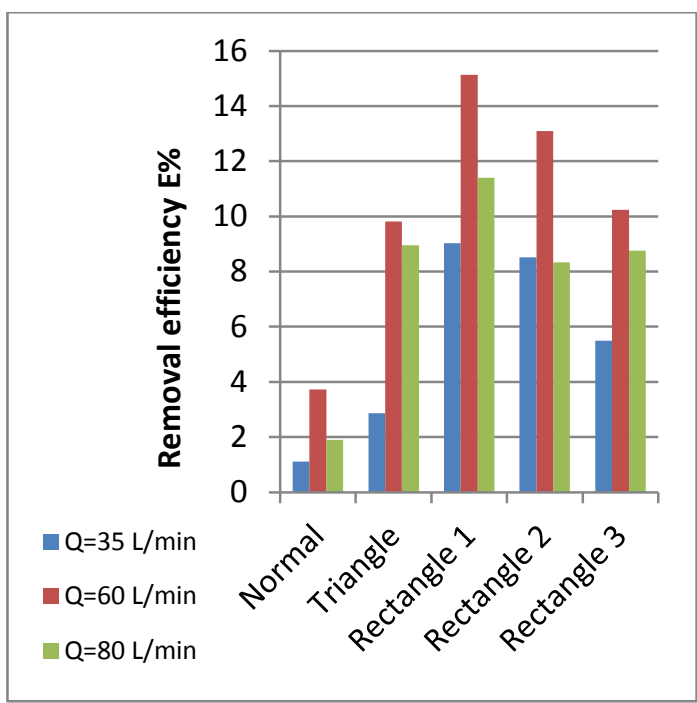

Figure 9: The relation between Removal efficiency $\mathrm{E} \%$ of $\mathrm{Mn}$ at different discharges for five shapes

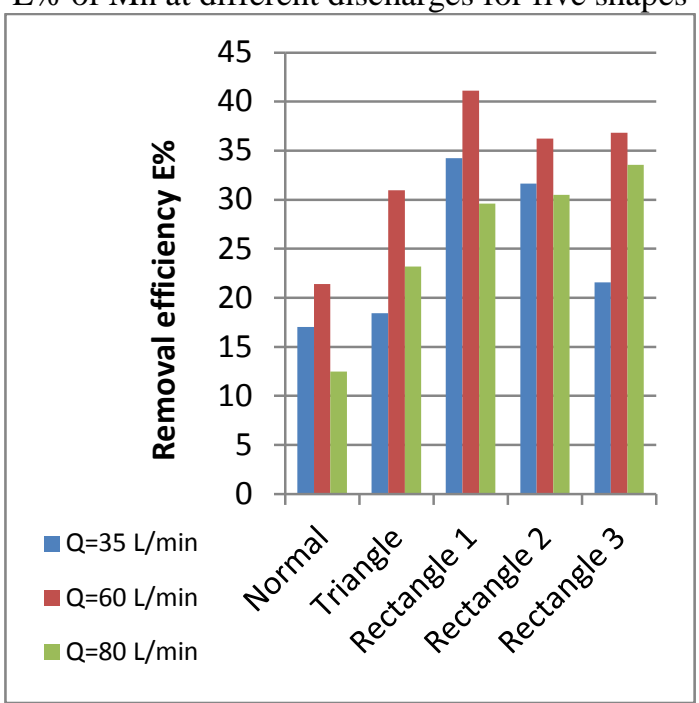

Figure 10: The relation between Removal efficiency E\% of Zn at different discharges for five shapes

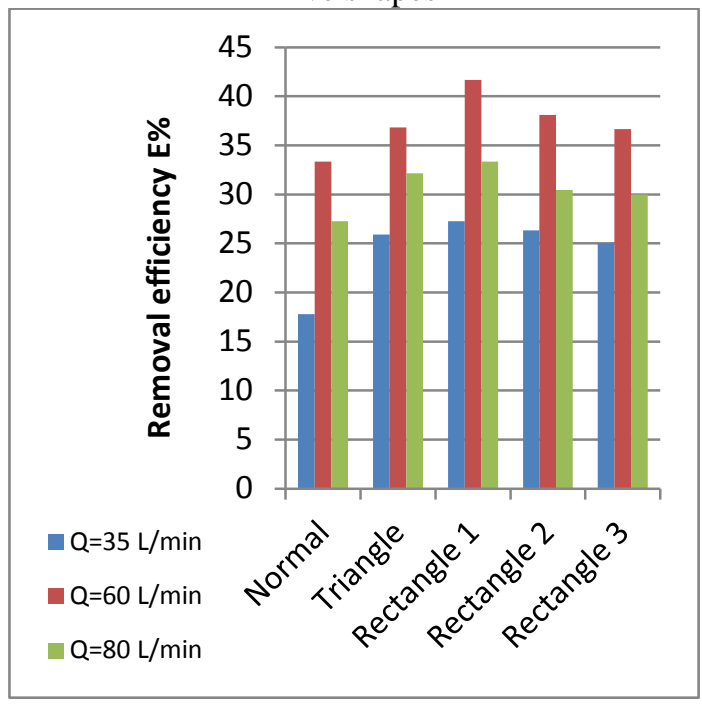

Figure 11: The relation between Removal efficiency $\mathrm{E} \%$ of $\mathrm{PO}_{4}$ at different discharges for five shapes

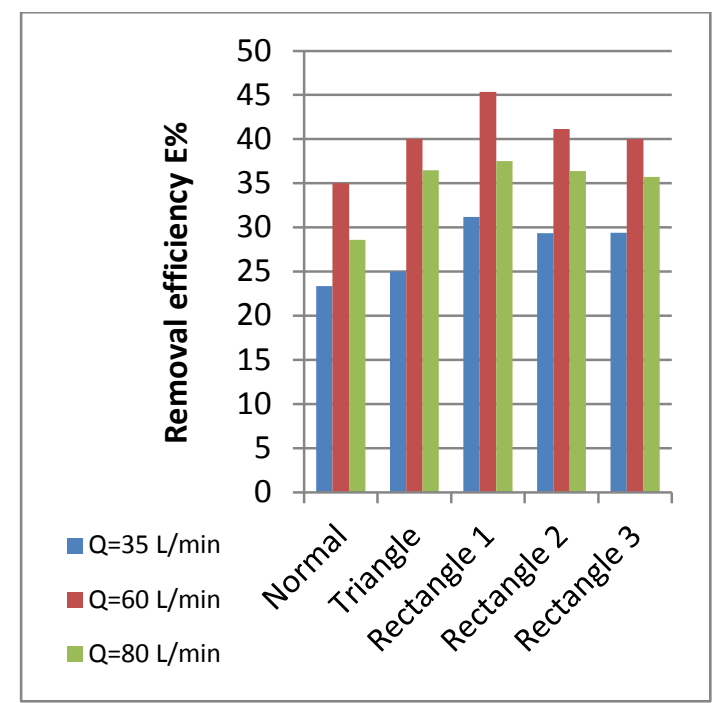

Figure 12: The relation between Removal efficiency $\mathrm{E} \%$ of CI at different discharges for five shapes

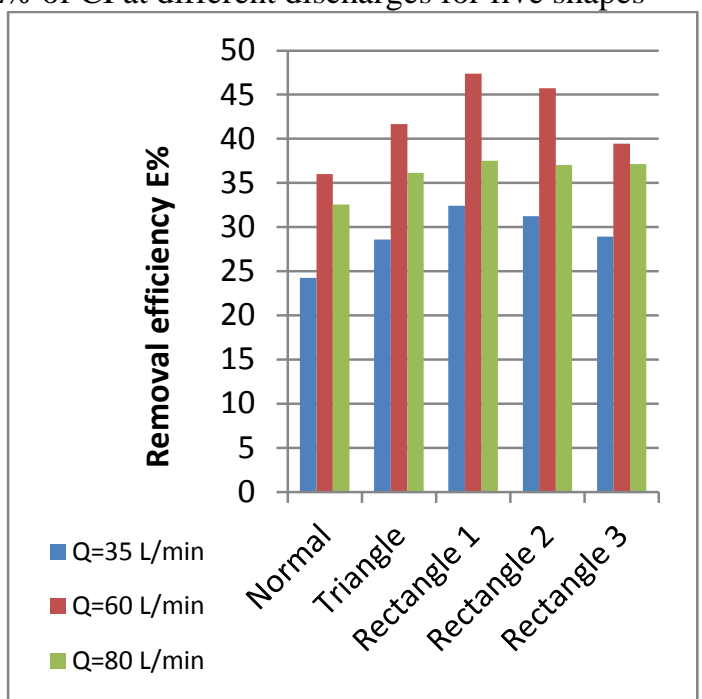

Figure 13: The relation between Removal efficiency $\mathrm{E} \%$ of $\mathrm{CIO}_{2}$ at different discharges for five shapes

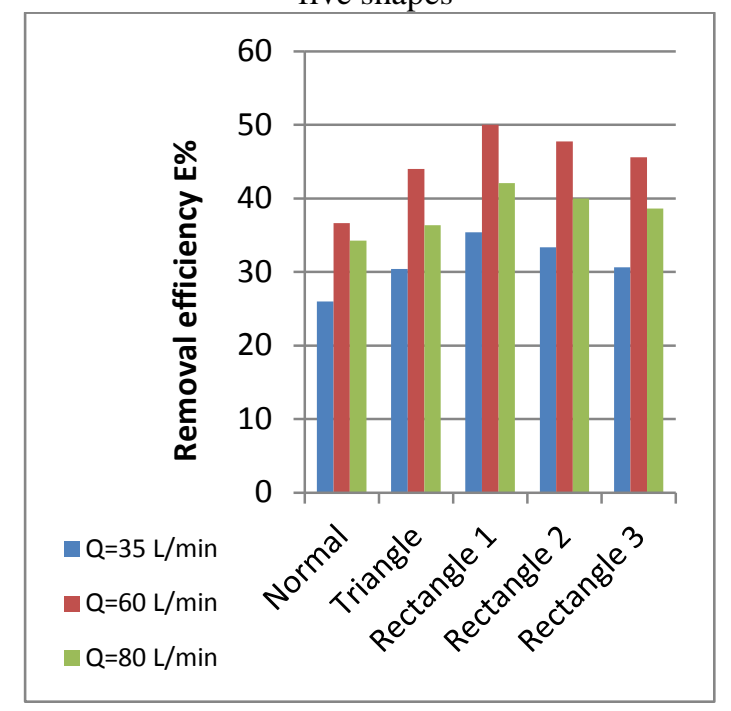

Figure 14: The relation between Removal efficiency $\mathrm{E} \%$ of $\mathrm{CaCO}_{3}$ at different discharges for five shapes 


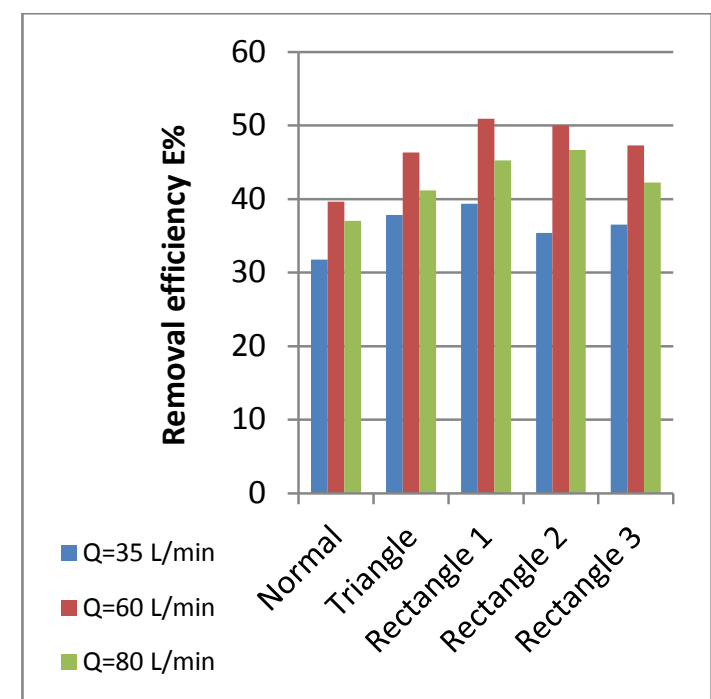

Figure 15: The relation between Removal efficiency $\mathrm{E} \%$ of $\mathrm{NO}_{2}$ at different discharges for five shapes

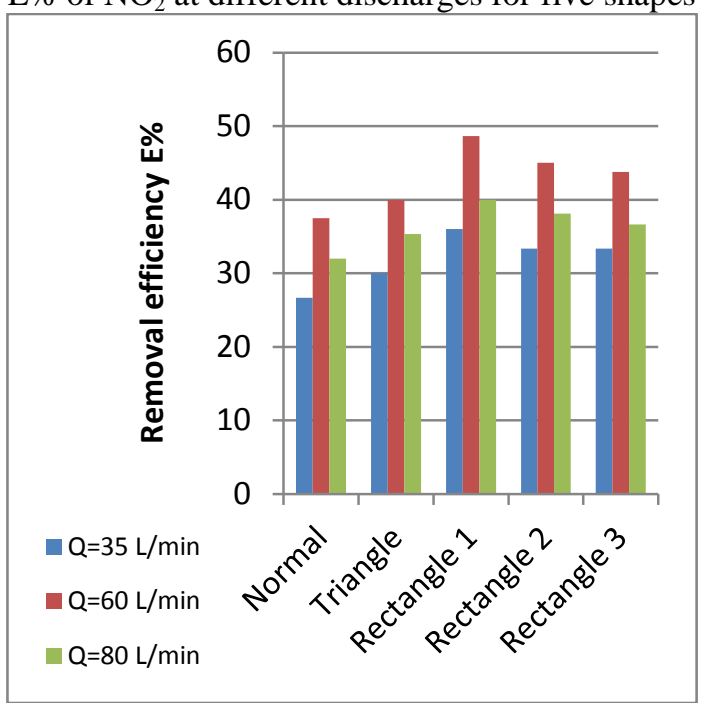

Figure 16: The relation between Removal efficiency $\mathrm{E} \%$ of $\mathrm{NH}_{3}$ at different discharges for five shapes.

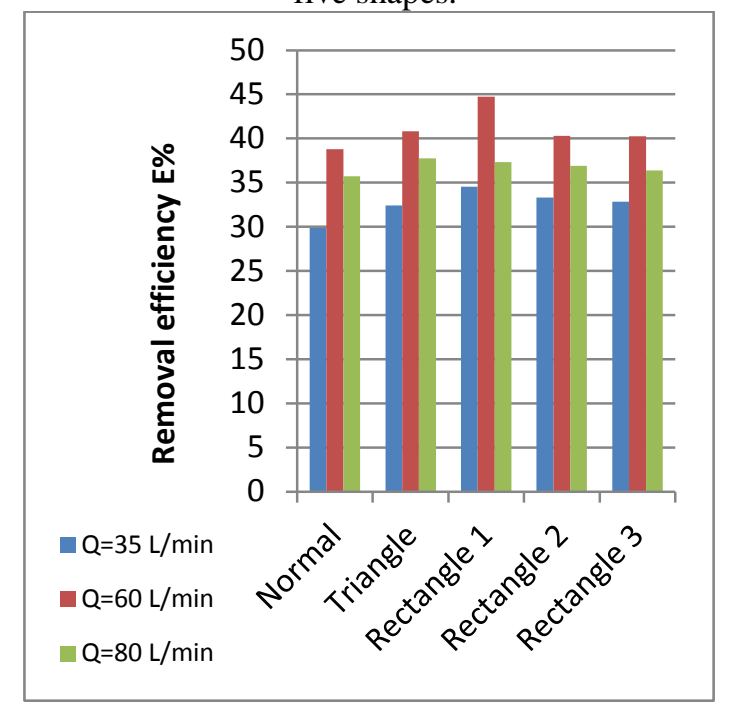

Figure 17: The relation between Removal efficiency E\% Toxic matter of at different discharges for five shapes
Although the aeration efficiency is increased at $80 \mathrm{~L} / \mathrm{min}$ but It should be considered that the retention time for the wastewater flowing over the stepped cascade is very short at $\mathrm{Q}=80 \mathrm{~L} / \mathrm{min}$,so the Removal efficiency $\mathrm{E} \%$ was greater at $\mathrm{Q}=60$ $\mathrm{L} / \mathrm{min}$ for all shapes Compared to other flow rates.

Stepped cascade weir removes or modifies the constituents of marginal water using two methods scrubbing action and oxidation action. Scrubbing action is caused by turbulence which results when the marginal water and air mix together. The scrubbing action physically removes gases from solution in the marginal water, allowing them to escape into the surrounding air. Carbon dioxide and hydrogen sulfide and chlorine $\left(\mathrm{Cl}^{-}\right)$can be removed by scrubbing action. Scrubbing action will remove tastes and odors from water if the problem is caused by relatively volatile gases and organic compounds, also aeration provides the dissolved oxygen needed to oxide the iron and manganese, it takes $0.14 \mathrm{mg} / \mathrm{L}$ of $\mathrm{O} 2$ to oxidize 1 $\mathrm{mg} / \mathrm{L}$ of iron; and $0.29 \mathrm{mg} / \mathrm{L}$ of $\mathrm{O} 2$ to oxidize 1 $\mathrm{mg} / \mathrm{L}$ of manganese.

Oxidation reaction of iron is:

$4 \mathrm{Fe}^{+2}+\mathrm{O}_{2}+10 \mathrm{H}_{2} \mathrm{O} \longrightarrow 4 \mathrm{Fe}(\mathrm{OH})_{3} \downarrow+8 \mathrm{H}^{+}$

Oxidation reaction of Manganese is:

$4 \mathrm{Mn}^{+2}+\mathrm{O}_{2}+2 \mathrm{H}_{2} \mathrm{O} \longrightarrow 4 \mathrm{MnOH}_{2} \downarrow+4 \mathrm{H}^{+}$

\section{4-3 Reduction efficiency of Biological Oxygen Demand $\left(\mathrm{BOD}_{5}\right)$ and Chemical Oxygen Demand (COD)}

Biochemical Oxygen Demand $\left(\mathrm{BOD}_{5}\right)$, is one of the most important and useful parameters indicating the strength of wastewater (amount of organic load/pollution). It is an estimate of the waste strength in terms of the amount of dissolved oxygen required by the microorganisms to break down the wastewater.

Figure (18) show that maximum Reduction efficiency $\mathrm{E} \%$ for rectangle 1 at $\mathrm{Q}=80 \mathrm{~L} / \mathrm{min}$ is $48 \%$, minimum Reduction efficiency $\mathrm{E} \%$ for normal shape at $\mathrm{Q}=35 \mathrm{~L} / \mathrm{min}$ is $16 \%$.

Chemical oxygen demand (COD) is a measure of chemical decomposition of organic and inorganic contaminants that consume dissolved oxygen.

Figure(19) show that maximum Reduction efficiency $\mathrm{E} \%$ for rectangle 1 at $\mathrm{Q}=80 \mathrm{~L} / \mathrm{min}$ is $47 \%$, minimum Reduction efficiency $\mathrm{E} \%$ for normal shape at $\mathrm{Q}=35 \mathrm{~L} / \mathrm{min}$ is $15.5 \%$.

The decay of organic matter in water is measured as biochemical or chemical oxygen demand. It should be considered that the retention time for the wastewater flowing over the stepped cascade is very short; thus the effect of microorganism to decompose the organic matter is little. 


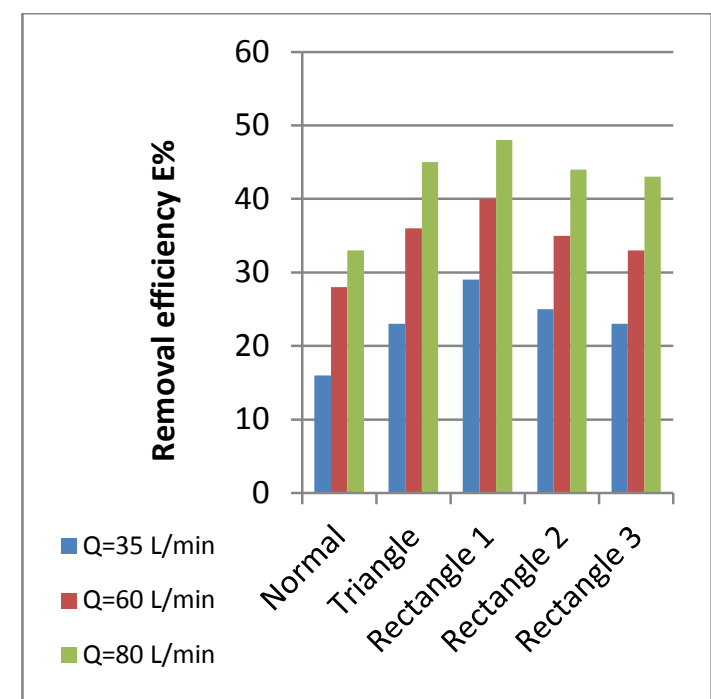

Figure 18: The relation between Removal efficiency $\mathrm{E} \%$ of $\mathrm{BOD}_{5}$ at different discharges for

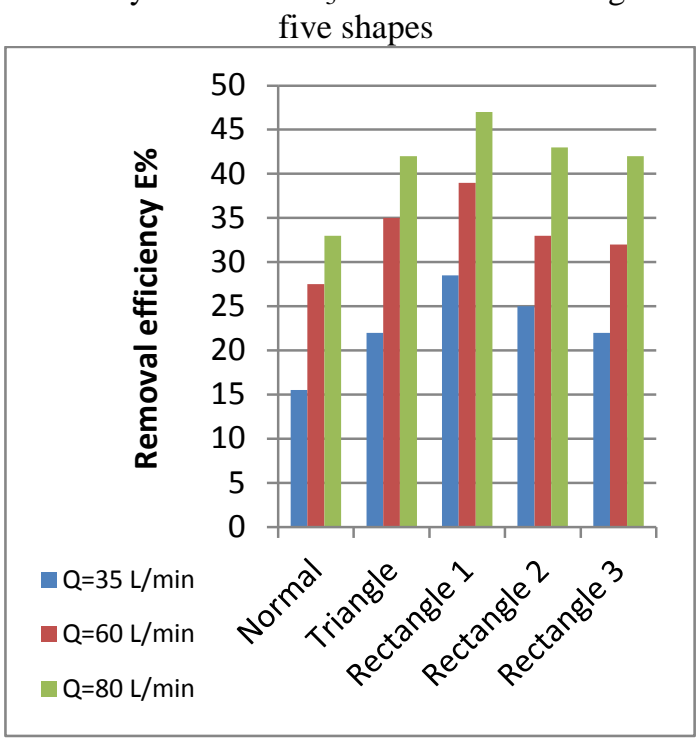

Figure 19: The relation between Removal efficiency E\% of COD at different discharges for five shapes

\section{5- Conclusions}

1- The results show that aeration efficiency increased as flow rates increased, maximum aeration efficiency is $45.7 \%$ for rectangle 1 notch at $80 \mathrm{~L} / \mathrm{min}$ and the minimum aeration efficiency is $23 \%$ for normal shape at $35 \mathrm{~L} / \mathrm{min}$.

2- Five different shapes of weir are used (Normal, Triangle, Rectangle1, Rectangle2 and Rectangle3). Results show the rectangle 1 is the best removal efficiency because this shape of weir contributes more oxygen transfer and greater turbulent mixing than the other shapes of weir.

3- The best removal efficiency of pollutant parameters $(\mathrm{Cu}),(\mathrm{Cr}),(\mathrm{Mo}),(\mathrm{Br}),(\mathrm{Fe}),(\mathrm{Mn})$,
(Zn), $\left(\mathrm{PO}_{4}\right),(\mathrm{Cl}),\left(\mathrm{ClO}_{2}\right)$, Hardness as $\mathrm{CaCO}_{3}$, $\left(\mathrm{NH}_{3}\right),\left(\mathrm{NO}_{2}\right)$ and Toxic matter) are recorded at flow rate $60 \mathrm{~L} / \mathrm{min}$ and shape rectangle 1 notch, Although the aeration efficiency is increased at $80 \mathrm{~L} / \mathrm{min}$ but it should be considered that the retention time for the wastewater flowing over the stepped cascade is very short at $\mathrm{Q}=80 \mathrm{~L} / \mathrm{min}$,so the removal efficiency was greater at $\mathrm{Q}=60 \mathrm{~L} / \mathrm{min}$ for all shapes Compared to other flow rates.

\section{References:}

[1] Asit. K. Biswas, A. Arar, "Use of marginal quality water for plant production in Europe", International Journal of Water Resources Development, England, Vol. 4 ,No. 2, PP. 127 - 141, 2010.

[2] C.L. Abbott, N.J. Hasnip, "The Safe Use of Marginal Quality Water in Agriculture ", Report OD 140, HR Wallingford ,England, 1997.

[3] A. Baylar, M. Unsal, , and F. ozkan, , " Hydraulic Structures in Water Aeration

Processes " , Water, Air,\& Soil Pollution , vol.210 , pp.87-100, 2010.

[4] D. Hanbay, A. Baylar, , And M. Batan, , "Prediction Of Aeration Efficiency On Stepped Cascades By Using Least Square Support Vector Machines" , Expert Systems With Applications ,vol.36 , no.3 ,pp. 42484252, 2009.

[5] Metcalf ,Inc. Eddy, " Wastewater Engineering Treatment and Reuse", McGraw Hill, New York, fourth edition, 2003.

[6] M. Kahil, H. Seif,"Natural Wastewater Treatment In Mountain Areas In Lebanon", european scientific journal,vol.10, no.14, pp.122-135, 2014.

[7] J. Nadayil, D.Mohan, K. Dileep, M. Rose,and R. R. P. Parambi," A Study on Effect of Aeration on Domestic Wastewater " International Journal of Interdisciplinary Research and Innovations, Vol. 3, pp: 10-15, 2015.

[8] L. Toombes, ," Experimental Study Of AirWater Flow Properties On Low-Gradient Stepped Cascades" , Ph.D. thesis, University of Queensland, Australia, 2002.

[9] O. El .Monayeri, , S. Bayoumi, and A. Khalifa, " Enhancement Of Self-Purification Of Streams Using Stepped Aeration", Tenth International Water Technology Conference,pp:307-316, 2006.

[10] A. Baylar, , T. Bagatur, , " Study of Aeration Efficiency at Weirs" ,Turk J Engin Environ Sci , vol.24 , pp.255-264, 2000. 


\section{تأثير شكل و ترتيب التهايات المغلقة للهدارات المتدرجة على نوعية المياه

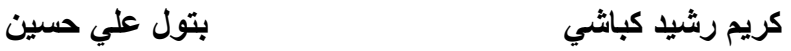

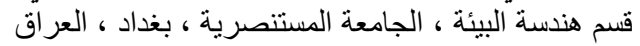 \\ batoolali53@yahoo.com \\ karimgubashi@yahoo.com}

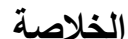

الهياكل الهيدروليكية يمكن اعتبار ها المكونات الرئيسية في تحسين كفاءة التهوية بسبب الاضطر اب القئ القوي للجريان المصاحب بدخول فقاعات

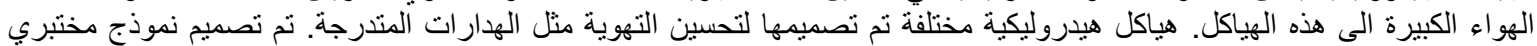

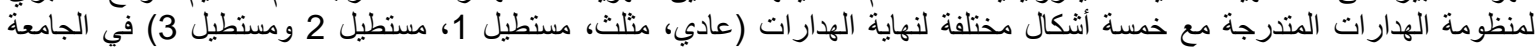

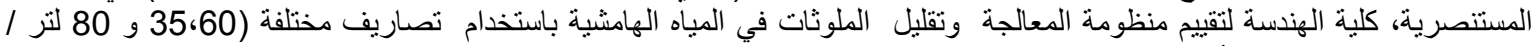

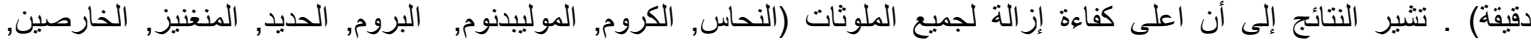

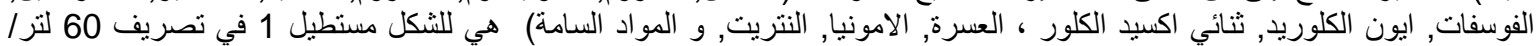

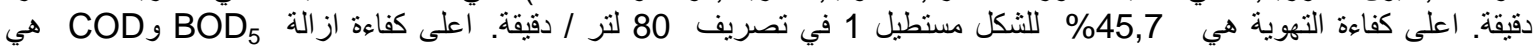

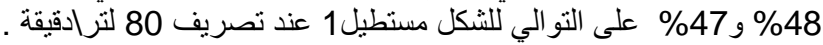

